\title{
KARAKTERISTIK EDIBLE FILM DARI KOMPOSIT ALGINAT, GLUTEN DAN LILIN LEBAH (BEESWAX)
}

\author{
Murdinah, Muhamad Darmawan dan Dina Fransiska*)
}

\begin{abstract}
ABSTRAK
Penelitian pembuatan edible film dari komposit alginat, gluten dan lilin lebah telah dilakukan. Pada percobaan ini dilakukan variasi rasio kompositnya (alginat : gluten : lilin lebah) masingmasing (A) : $1: 1: 1 ;(B): 1: 1: 2 ;(C): 1: 2: 1$ dan (D) $: 2: 1: 1$. Karakteristik edible film yang diamati adalah sifat fisik (ketebalan, kuat tarik, persen pemanjangan dan laju transmisi uap air), kadar air, dan pengujian organoleptik (warna, penampakan dan tekstur). Dari hasil penelitian diketahui bahwa komposit edible film tidak berpengaruh terhadap kadar air, ketebalan, dan kuat tarik tetapi berpengaruh nyata terhadap persen pemanjangan dan laju transmisi uap airnya. Pada uji organoleptik, variasi rasio komposit tidak berpengaruh nyata terhadap warna, penampakan dan tekstur.
\end{abstract}

ABSTRACT: Characteristics of composite edible film made from alginate, gluten and beeswax. By: Murdinah, Muhamad Darmawan and Dina Fransiska

Study on the processing of edible film from the composite of alginate, gluten and beeswax has been carried out. In this study, the composite ratio (alginate; gluten; beeswax) varied i.e. (A) $1: 1$ $: 1$, (B) $1: 1: 2$, (C) $1: 2: 1$ and (D) $2: 1: 1$. The characteristics of edible film composite observed were physical parameter (thickness, tensile strength, elongation, and water vaporated transmision rate), moisture content, organoleptic test (colour, texture, appearance). The result showed that the composite ratio of edible film did not significantly influence moisture content, thickness, and tensile strength but significantly affected the elongation and water vaporated transmission rate. In terms of organoleptic assesment, colour, appearance, and texture were not affected by all treatment used in the experiment.

KEYWORDS: composite edible film, alginate, gluten, beeswax

\section{PENDAHULUAN}

Selama ini pengemas yang paling populer adalah pengemas plastik. Pengemas plastik yang umum digunakan untuk mengemas bahan pangan adalah jenis polietilen dan polistiren. Meskipun penggunaan plastik banyak kelebihannya namun mempunyai banyak kelemahan yaitu tidak dapat terdegradasi secara biologis dan kemungkinan adanya zat-zat berbahaya yang dapat termigrasi ke dalam bahan pangan. Dengan adanya persyaratan bahwa kemasan yang digunakan adalah kemasan yang ramah lingkungan, maka penggunaan edible film adalah sesuatu yang sangat menjanjikan. Kelebihan edible film dibanding pengemas plastik yang umum digunakan adalah melindungi produk pangan, penampakan asli produk dapat dipertahankan, dapat langsung dimakan dan aman bagi lingkungan (Kinzel, 1992).

Edible film adalah lapisan tipis dan kontinyu terbuat dari bahan-bahan yang dapat dimakan, dibentuk melapisi komponen makanan (coating) atau diletakkan di antara komponen makanan (film) yang berfungsi sebagai barrier terhadap transfer massa (misalnya kelembaban, oksigen, lipid, cahaya dan zat terlarut), dan sebagai carrier bahan makanan dan bahan tambahan, serta untuk meningkatkan penanganan suatu makanan (Krochta \& Johnston, 1997).

Menurut Donhowe \& Fennema (1994), komponen utama penyusun edible film dapat dikelompokkan menjadi tiga kategori, yaitu hidrokoloid, lipid, dan komposit. Komposit merupakan gabungan dari hidrokoloid dan lipid. Hidrokoloid yang dapat digunakan untuk membuat edible film adalah protein dan karbohidrat. Sedangkan lipid yang digunakan adalah lilin/wax dan asam lemak.

Alginat merupakan hidrokoloid polisakarida yang potensial untuk dibuat edible film, karena sifatnya yang kaku, dapat dimakan dan dapat diperbaharui (Carriedo, 1994). Alginat merupakan produk yang

Peneliti pada Balai Besar Riset Pengolahan Produk dan Bioteknologi Kelautan dan Perikanan, DKP 
dihasilkan dari proses ekstraksi rumput laut coklat. Pembuatan edible film dari alginat merupakan salah satu upaya untuk meningkatkan pemanfaatan rumput laut.

Edible film yang dibuat dari hidrokoloid mempunyai beberapa kelebihan, di antaranya baik untuk melindungi produk terhadap oksigen, karbondioksida dan lipid, meningkatkan kesatuan struktural produk, dan memiliki sifat mekanis yang diinginkan. Adapun kekurangannya yaitu film dari karbohidrat kurang bagus digunakan untuk mengatur migrasi uap air, dan film dari protein biasanya sangat dipengaruhi oleh perubahan $\mathrm{pH}$. Edible film dari lipid mempunyai kelebihan yaitu baik digunakan untuk melindungi produk dari penguapan air atau sebagai bahan pelapis untuk mengoles produk konfeksioneri. Sedangkan kekurangannya yaitu kegunaannya dalam bentuk murni sebagai film terbatas, karena integritas dan ketahanannya rendah. Edible film dari komposit (gabungan hidrokoloid dan lipid) dapat meningkatkan kelebihan dari film hidrokoloid dan lipid, serta mengurangi kelemahannya (Downhowe \& Fennema, 1994).

Salah satu komponen yang ditambahkan dalam pembuatan edible film adalah plasticizer. Penambahan plasticizer pada edible film ini penting untuk mengatasi sifat rapuh film yang disebabkan kekuatan intermolekul ekstensif. Jenis plasticizeryang paling banyak digunakan antara lain poliglikol, monosakarida, mono oligosakarida, di oligosakarida, lipid dan turunannya seperti gliserol, dan beeswax (Gontard et al., 1993).

McHugh \& Krochta (1994) menyatakan bahwa penting sekali mengetahui sifat-sifat edible film sebelum diaplikasikan untuk mengemas suatu produk pangan. Menurut Downhowe \& Fennema (1994), beberapa uji telah dikembangkan untuk menentukan sifat permeabilitas, karakteristik fisik, dan karakteristik mekanik edible film yang didasarkan pada metode uji standar untuk nonedible films. Uji-uji tersebut di antaranya, sifat permeabilitas uap air, sifat permeabilitas zat terlarut, dan sifat permeabilitas lemak, kuat tarik dan persen elongasi, berat dasar, ketebalan film, dan uji-uji lainnya.

Tujuan dari penelitian ini adalah untuk membuat dan mengetahui karakteristik edible film yang dibuat dari komposit alginat, gluten dan lilin lebah.

\section{BAHAN DAN METODE}

\section{Bahan}

Bahan-bahan yang digunakan dalam penelitian ini adalah alginat yang diekstraksi dari rumput laut
Sargassum filipendula dengan menggunakan metode ekstraksi Yunizal (2000). Bahan kimia yang digunakan untuk ekstraksi alginat adalah $\mathrm{HCl}, \mathrm{Na}_{2} \mathrm{CO}_{3}$, $\mathrm{NaOCl}, \mathrm{NaOH}$ dan isopropil alkohol (IPA). Sedangkan bahan yang digunakan untuk pembuatan edible film adalah akuades, gluten, lilin lebah, etanol, dan gliserol yang diperoleh dari Bogor.

\section{Alat}

Alat-alat yang digunakan untuk pembuatan edible film adalah gelas beaker, gelas ukur, hot plate stirrer, magnetic stirrer, termometer, oven, dan kaca ukuran $20 \times 30 \mathrm{~cm}^{2}$.

\section{Metode}

Pada penelitian ini dilakukan pembuatan edible film dari 4 variabel perlakuan yaitu perbandingan komposit antara alginat, gluten dan lilin lebah. Variabel perlakuan adalah sebagai berikut:

A : alginat : gluten : lilin lebah $=1: 1: 1$

$B$ : alginat : gluten : lilin lebah $=1: 1: 2$

$C:$ alginat : gluten : lilin lebah $=1: 2: 1$

$D:$ alginat : gluten : lilin lebah $=2: 1: 1$

Pembuatan edible film mengacu pada metode Melia (1997) yang dimodifikasi. Modifikasi yang dilakukan adalah penambahan gluten dan penambahan etanol ke dalam gluten dan lilin lebah. Edible film dibuat dengan menambahkan $5 \mathrm{~g}$ campuran antara alginat, gluten, dan lilin lebah dengan rasio campuran sesuai variasi perlakuan $(A, B, C$, dan D) dalam $100 \mathrm{~mL}$ pelarut (akuades dan etanol) sebagai berikut. Bubuk alginat ditambah dengan $60 \mathrm{~mL}$ air kemudian dipanaskan pada suhu $80^{\circ} \mathrm{C}$ selama 15 menit sambil diaduk dengan magnetic stirrer sampai homogen. Gluten dilarutkan dalam etanol $15 \mathrm{~mL}$ dan akuades $15 \mathrm{~mL}$, kemudian ditambahkan ke dalam larutan alginat dan dipanaskan pada suhu $80^{\circ} \mathrm{C}$ selama 15 menit. Campuran ini diturunkan suhunya menjadi $55-60^{\circ} \mathrm{C}$ dan dilakukan penambahan gliserol sebanyak $1 \mathrm{~mL}$ kemudian dipanaskan lagi sampai suhu $67-72^{\circ} \mathrm{C}$. Lilin lebah yang telah dilarutkan dalam $10 \mathrm{~mL}$ etanol kemudian ditambahkan ke dalam campuran ini dan dipanaskan pada suhu $70^{\circ} \mathrm{C}$ selama 30 menit. Setelah itu dilakukan pencetakan di lempeng kaca dan dikeringkan di oven pada suhu $60^{\circ} \mathrm{C}$ selama 3-5 jam. Edible film kemudian dilepaskan dari lempeng kaca dan dibungkus dengan aluminium foil. Rancangan percobaan yang digunakan dalam penelitian ini adalah rancangan acak lengkap dengan 2 kali ulangan (Steel \& Torrie, 1995).

Pengamatan yang dilakukan dalam penelitian ini adalah pengamatan terhadap sifat fisik yang meliputi ketebalan edible film yang diukur dengan 
menggunakan alat microcal meshmeter, kuat tarik dengan menggunakan alat Testing Machine MPY, persentase pemanjangan yang diukur dengan menggunakan elongation tester sterograph, dan laju transmisi uap air yang diukur dengan metode cawan (ASTM, 1983). Analisis kimia yang dilakukan adalah kadar air (Apriyantono et al., 1989). Uji organoleptik dari edible film meliputi parameter warna, penampakan dan tekstur (Soekarto, 1985). Pengujian organoleptik dilakukan dengan menggunakan skala hedonik 1 sampai 9 untuk mengetahui tingkat kesukaan panelis terhadap edible film yang dihasilkan.

\section{HASIL DAN BAHASAN}

\section{Ketebalan Edible Film}

Ketebalan edible film yang diperoleh berkisar antara 0,07-0,11 mm (Gambar 1).

Dari hasil analisis statistik diketahui bahwa semua perlakuan tidak memberikan pengaruh yang nyata terhadap ketebalan film yang dihasilkan. Hasil penelitian Irianto et al. (2006) memperlihatkan bahwa edible film yang dibuat dari karaginan, tapioka dan lilin lebah menghasilkan ketebalan berkisar antara
0,05-0,08 mm. Hasil penelitian Budi Santoso (2006) pada pembuatan edible film dengan bahan kolangkaling dan lilin lebah mempunyai nilai ketebalan berkisar antara 0,005-0,025 mm. Bila dibandingkan dengan hasil penelitian Irianto et al. (2006) dan Budi Santoso (2006) maka ketebalan edible film yang dihasilkan pada penelitian ini lebih tinggi.

\section{Kuat Tarik}

Kuat tarik film merupakan tarikan maksimal yang dapat dicapai sampai film tetap bertahan sebelum film sobek. Nilai kuat tarik edible film dari komposit hidrokoloid dan lipid berkisar antara 136,75-355,56 $\mathrm{kgf} / \mathrm{cm}^{2}$ (Gambar 2). Sifat kuat tarik merupakan sifat fisik yang berhubungan dengan kekuatan film untuk menahan kerusakan fisik pada saat pengemasan. Film dengan nilai kuat tarik paling tinggi diharapkan dapat menahan kerusakan fisik maksimal, sehingga kerusakan yang akan diterima produk menjadi minimal.

Dari hasil analisis statistik diketahui bahwa semua perlakuan tidak memberikan pengaruh yang nyata terhadap kuat tarik edible film yang dihasilkan. Kuat tarik yang dihasilkan dari penelitian Budi Santoso (2006) adalah berkisar antara 0,079-0,342 kgf/cm²

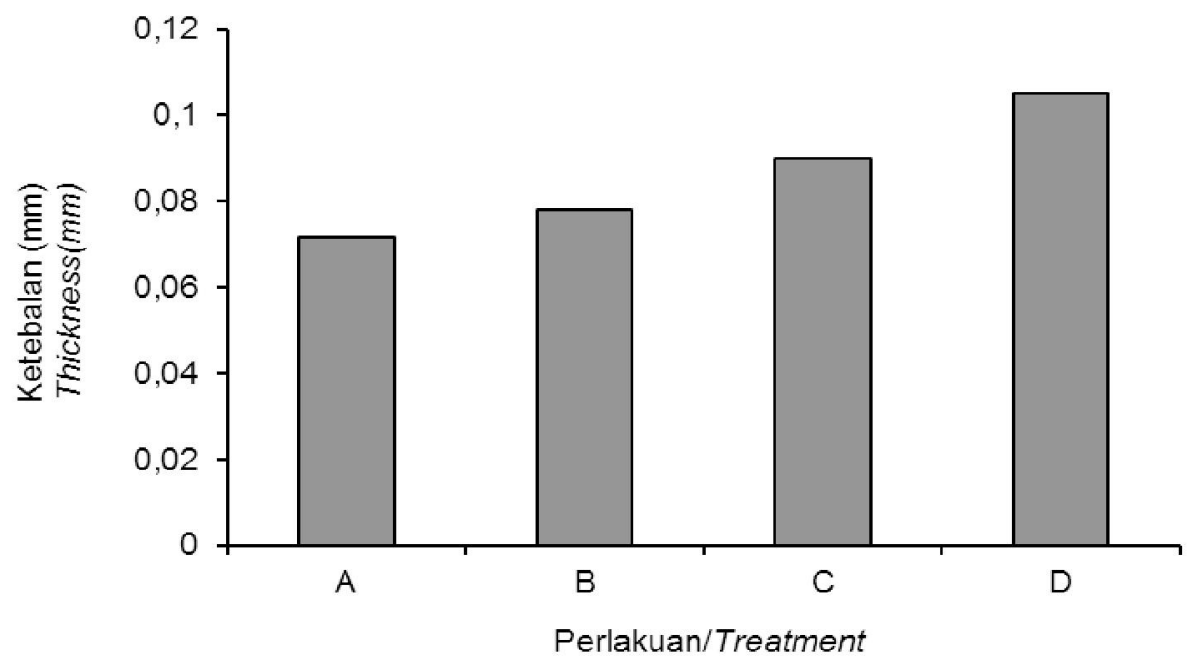

Gambar 1. Ketebalan edible film ( $\mathrm{mm})$.

Figure 1. Thickness of edible film ( $\mathrm{mm})$.

Keterangan/Note :
A : Alginat/alginate : gluten/gluten : lilin lebah/beeswax $=1: 1: 1$
B : Alginat/alginate : gluten/gluten : lilin lebah/beeswax $=1: 1: 2$
C : Alginat/alginate : gluten/gluten : lilin lebah/beeswax $=1: 2: 1$
$\mathrm{D}:$ Alginat/alginate $:$ gluten/gluten $:$ lilin lebah/beeswax $=2: 1: 1$ 


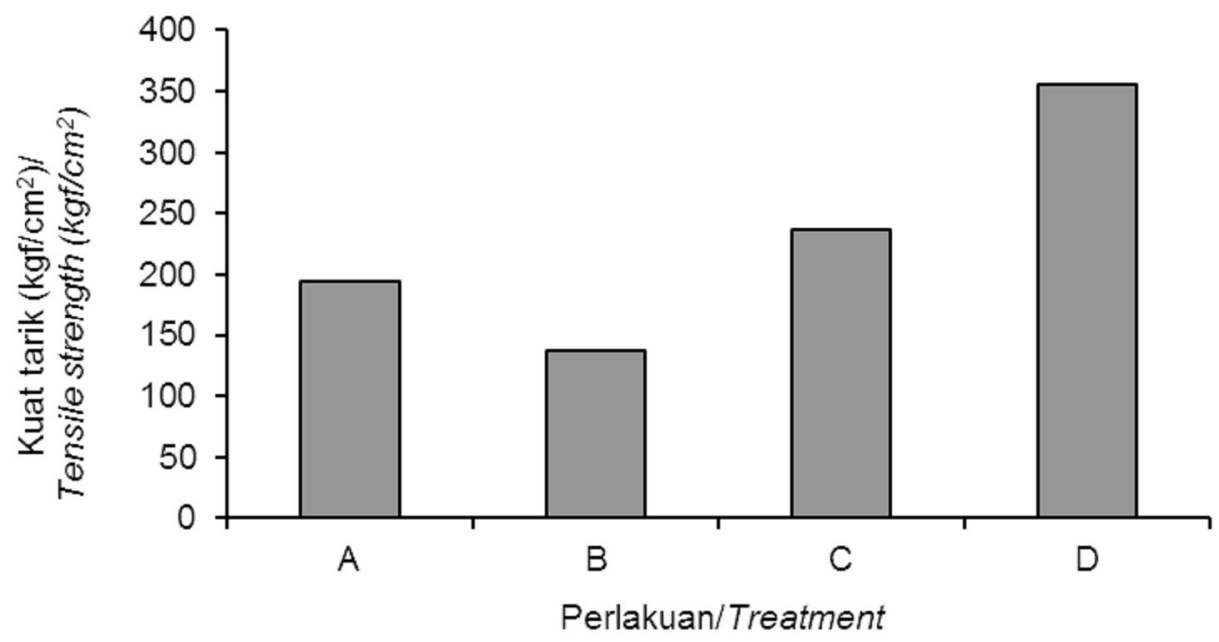

Gambar 2. Kekuatan tarik edible film $\left(\mathrm{kgf} / \mathrm{cm}^{2}\right)$.

Figure 2. Tensile strength of edible film $\left(\mathrm{kgf} / \mathrm{cm}^{2}\right)$.

Keterangan/Note :
A : Alginat/alginate : gluten/gluten : lilin lebah/beeswax $=1: 1: 1$
B : Alginat/alginate : gluten/gluten : lilin lebah/beeswax $=1: 1: 2$
C : Alginat/alginate : gluten/gluten : lilin lebah/beeswax $=1: 2: 1$
$\mathrm{D}:$ Alginat/alginate : gluten/gluten : lilin lebah/beeswax $=2: 1: 1$

sedangkan kuat tarik edible film yang dihasilkan dari penelitian ini berkisar antara 136,75-355,56 kgf/ $\mathrm{cm}^{2}$. Kuat tarik yang dihasilkan pada penelitian ini lebih besar dibandingkan dengan kuat tarik yang dihasilkan pada penelitian di atas.

\section{Persen Pemanjangan}

Hasil pengukuran persen pemanjangan edible film dari komposit hidrokoloid dan lipid berkisar antara 1,02,5\% (Gambar 3). Persen pemanjangan merupakan

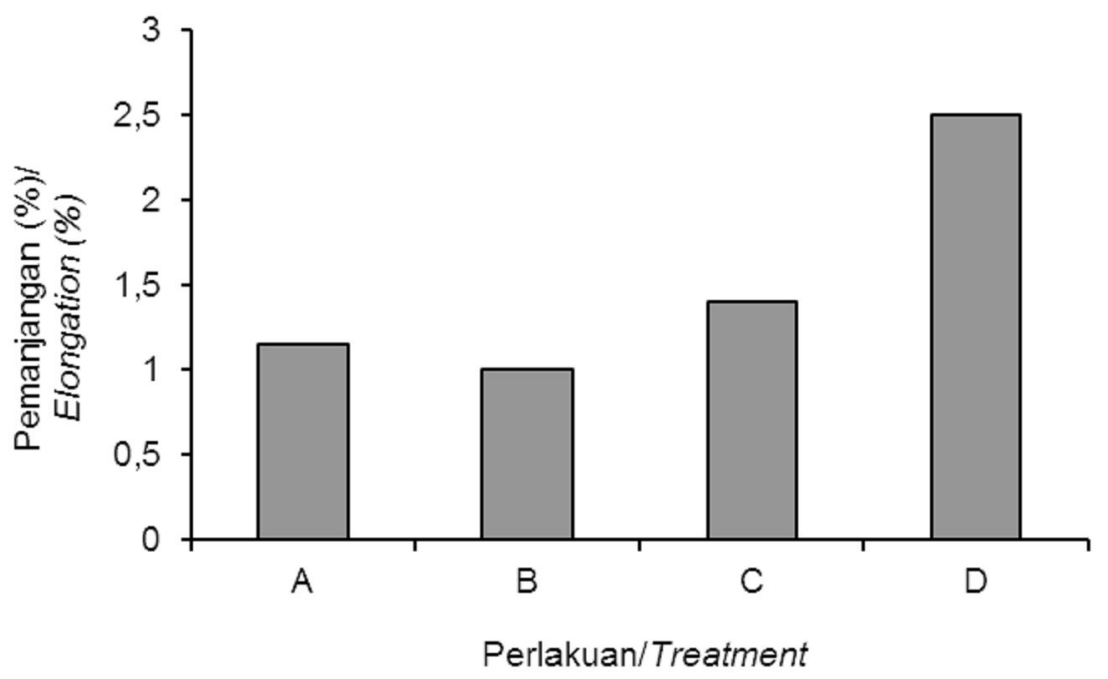

Gambar 3. Persentase pemanjangan edible film (\%).

Figure 3. Elongation of edible film (\%).

Keterangan/Note :

A : Alginat/alginate : gluten/gluten : lilin lebah/beeswax $=1: 1: 1$

B : Alginat/alginate : gluten/gluten : lilin lebah/beeswax $=1: 1: 2$

C : Alginat/alginate : gluten/gluten : lilin lebah/beeswax $=1: 2: 1$

$\mathrm{D}:$ Alginat/alginate : gluten/gluten : lilin lebah/beeswax $=2: 1: 1$ 
persentase perubahan panjang film pada saat film ditarik. Perubahan panjang tersebut dapat dilihat pada saat film sobek. Pada penelitian ini, persen pemanjangan tertinggi didapatkan pada perlakuan komposit alginat, gluten dan lilin lebah dengan perbandingan 2 : 1 : 1 sedangkan persen pemanjangan terendah dari perlakuan komposit alginat, gluten dan lilin lebah dengan perbandingan 1 $: 1: 2$.

Hasil analisis statistik menunjukkan bahwa perlakuan yang diberikan berpengaruh nyata terhadap persen pemanjangan edible film. Perlakuan edible film dengan komposisi komposit $\mathrm{D}(2: 1: 1)$ berbeda dengan rasio komposit yang lain. Penggunaan alginat dalam jumlah yang lebih besar menyebabkan kemampuan mengikat air lebih baik sehingga menghasilkan matrik gel yang dapat meningkatkan persen pemanjangan edible film. Hasil yang sama ditunjukkan oleh penelitian Irianto et al. (2006) bahwa semakin tinggi konsentrasi hidrokoloid karaginan akan meningkatkan persen pemanjangan edible film.

Hasil penelitian Budi Santoso (2006) menunjukkan bahwa penambahan lilin lebah dengan konsentrasi yang lebih besar akan menurunkan nilai persen pemanjangan. Hal ini disebabkan lilin lebah memiliki efek anti plasticizing sehingga akan menghasilkan edible film yang keras, kaku, dan tidak fleksibel sehingga mudah patah yang menyebabkan persen pemanjangan menjadi rendah.

Persentase pemanjangan menurut Krochta \& Johston (1997) dikategorikan kurang baik jika kurang dari $10 \%$ dan dikategorikan baik jika persentase pemanjangannya lebih dari $50 \%$. Persen pemanjangan edible film dari komposit hidrokoloid dan lipid yang dihasilkan pada penelitian ini tergolong kurang baik karena memiliki nilai kurang dari 10\%.

\section{Laju Transmisi Uap Air}

Beberapa jenis produk pangan sensitif terhadap uap air. Edible film dapat mencegah penyerapan uap air jika digunakan pada permukaan produk pangan.

Nilai rata-rata laju transmisi uap air yang dihasilkan komposit alginat, gluten dan lilin lebah berkisar antara $154,34-284,40 \mathrm{~g} / \mathrm{m}^{2} / 24$ jam (Gambar 4). Nilai tertinggi diperoleh dari perlakuan komposit alginat, gluten dan lilin lebah dengan perbandingan $2: 1: 1$. Nilai laju transmisi uap air terendah diperoleh dari perlakuan komposit alginat, gluten dan lilin lebah dengan perbandingan $1: 1: 2$.

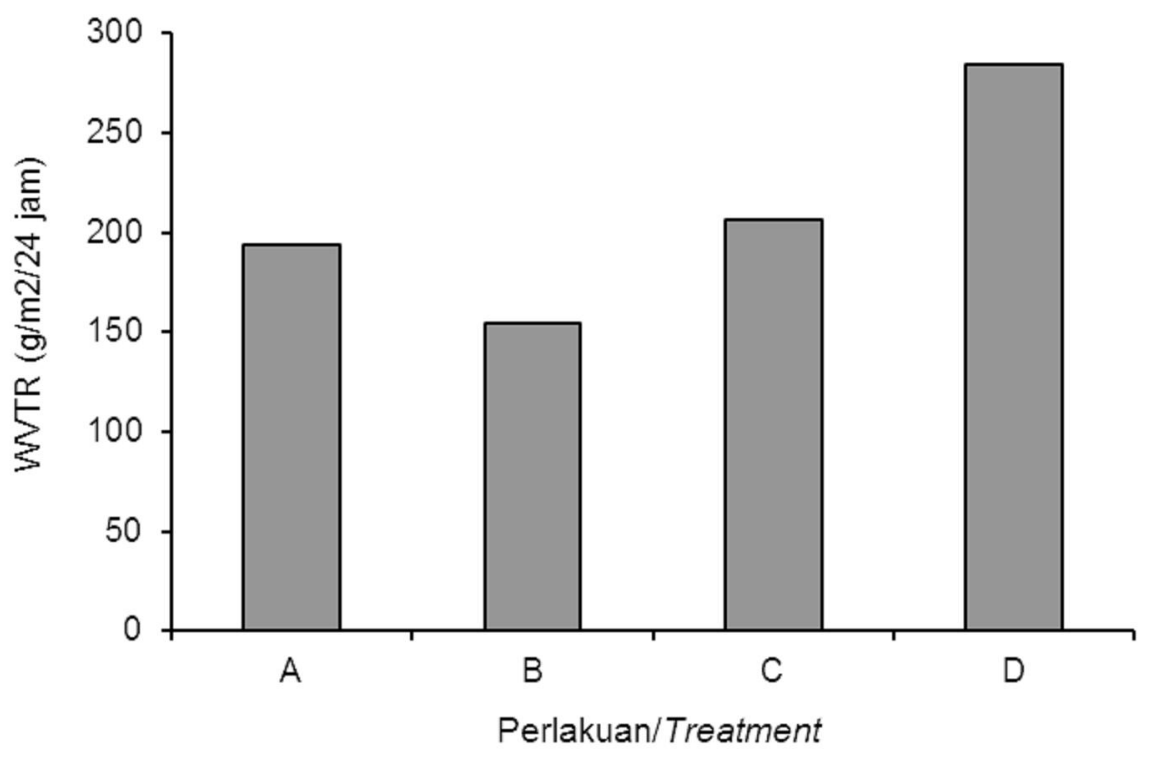

Gambar 4. Nilai laju transmisi uap air edible film.

Figure 4. Water vaporation transmision rate value of edible film.

Keterangan/Note :

A : Alginat/alginate : gluten/gluten : lilin lebah/beeswax $=1: 1: 1$

B : Alginat/alginate : gluten/gluten : lilin lebah/beeswax $=1: 1: 2$

C : Alginat/alginate : gluten/gluten : lilin lebah/beeswax $=1: 2: 1$

$\mathrm{D}:$ Alginat/alginate $:$ gluten/gluten $:$ lilin lebah/beeswax $=2: 1: 1$ 
Hasil analisis statistik menunjukkan bahwa perlakuan yang diberikan berpengaruh nyata terhadap laju transmisi uap air edible film yang dihasilkan. Laju transmisi uap air edible film dengan rasio komposit $D$ ( $2: 1: 1)$ berbeda dengan rasio komposit yang lain. Konsentrasi alginat yang tinggi menghasilkan nilai laju transmisi uap air yang tinggi pula. Hal ini disebabkan sifat alginat yang mampu mengikat air lebih baik sehingga menghasilkan matrik gel yang dapat meningkatkan laju transmisi uap air edible film.

Laju transmisi uap air yang dihasilkan dari penelitian Irianto et al. (2006) adalah berkisar antara $746,2-1117,4 \mathrm{~g} / \mathrm{m}^{2} /$ hari. Laju transmisi uap air yang dihasilkan pada penelitian ini lebih baik bila dibandingkan dengan laju transmisi uap air yang dihasilkan pada penelitian Irianto et al. (2006). Hal ini dikarenakan penggunaan lilin lebah pada penelitian ini lebih banyak bila dibandingkan dengan penelitian di atas.

Dari penelitian ini dapat diasumsikan bahwa untuk mendapatkan nilai laju transmisi uap air yang rendah, disarankan menggunakan komposisi komposit B (1: $1: 2)$ karena lilin lebah memiliki sifat hidrofobik. Menurut Deberaufort et al. (1993), laju transmisi uap air akan menurun dengan meningkatnya sifat hidrofobik. Lipid merupakan komponen yang paling efektif sebagai barier terhadap uap air, oleh karena itu perlu penambahan komponen lipid dalam edible film karena lilin lebah membentuk jaringan kristal sehingga dapat berfungsi sebagai penghalang terhadap uap air.

\section{Kadar Air}

Dari hasil analisis statistik diketahui bahwa semua perlakuan tidak berpengaruh nyata terhadap kadar air edible film yang dihasilkan. Nilai rata-rata kadar air edible film komposit alginat, gluten dan lilin lebah berkisar antara 21,95-24,63\% (Gambar 5). Hasil penelitian Suryaningrum et al. (2005) dalam pembuatan edible film dengan bahan hidrokoloid karaginan dan tapioka mempunyai nilai kadar air berkisar antara 12,87-17,34\%. Bila dibandingkan dengan hasil penelitian di atas maka nilai kadar air yang dihasilkan pada penelitian ini lebih besar. Hal ini diduga karena kemampuan alginat dalam mengikat air lebih baik daripada karaginan sehingga edible film yang dihasilkan memiliki kadar air yang lebih tinggi dibandingkan dengan hasil penelitian Suryaningrum et al. (2005).

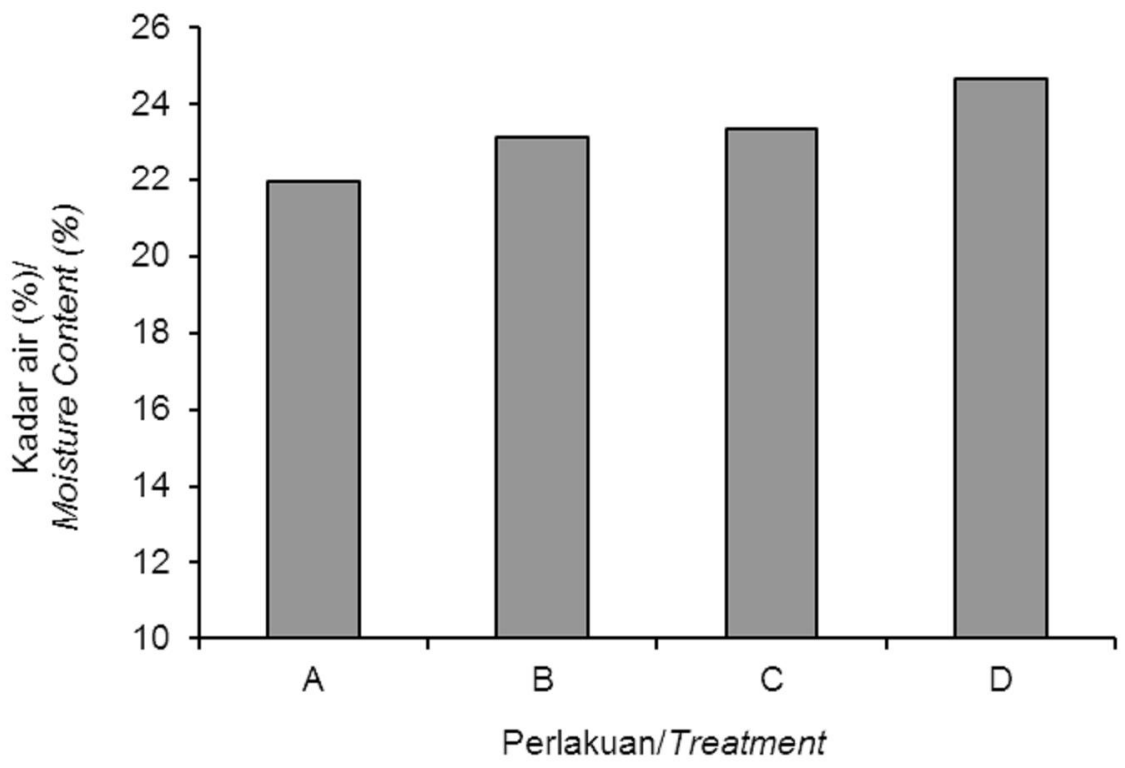

Gambar 5. Nilai kadar air edible film (\%).

Figure 5. Moisture content of edible film (\%).

Keterangan/Note :

A : Alginat/alginate : gluten/g/uten $:$ lilin lebah/beeswax $=1: 1: 1$

B : Alginat/alginate : gluten/gluten : lilin lebah/beeswax $=1: 1: 2$

C : Alginat/alginate : gluten/gluten : lilin lebah/beeswax $=1: 2: 1$

$\mathrm{D}:$ Alginat/alginate $:$ gluten/gluten $:$ lilin lebah/beeswax $=2: 1: 1$ 


\section{Uji Organoleptik}

Hasil uji Kruskal-Wallis menunjukkan bahwa perlakuan yang diberikan tidak berpengaruh nyata terhadap warna, penampakan dan tekstur edible film yang dihasilkan.

Dari hasil uji organoleptik terhadap parameter tekstur diketahui bahwa penilaian panelis berkisar antara 5,4-6,3 dengan kriteria biasa sampai dengan agak suka, nilai warna berkisar antara 4,9-6,0 yaitu dengan kriteria kurang suka sampai dengan agak suka, sedangkan untuk parameter penampakan diketahui bahwa penilaian panelis berkisar antara 5,46,2 dengan kriteria biasa sampai dengan agak suka.

\section{KESIMPULAN}

Berdasarkan penelitian yang telah dilakukan dapat disimpulkan bahwa rasio komposit tidak berpengaruh nyata terhadap nilai kadar air, ketebalan, kuat tarik, dan uji organoleptik (warna, penampakan, tekstur) tetapi berpengaruh terhadap persen pemanjangan dan laju transmisi uap air. Dari segi nilai laju transmisi uap air, rasio komposit alginat: gluten : lilin lebah (1 $: 1: 2$ ) adalah yang terbaik dibandingkan dengan rasio komposit yang lain.

\section{DAFTAR PUSTAKA}

Apriyantono, A., Fardiaz, D., Puspitasari, N.L., Sedarnawati dan Budiyanto. 1989. Analisis Pangan. Pusat Antar Universitas Pangan dan Gizi, IPB. Bogor. $229 \mathrm{pp}$.

ASTM. 1983. Annual Book of ASTM Standard. American Society for Testing and Material. Philadelphia. 247 pp.

Carriedo, MN. 1994. edible coating and film based on polysccharides. In Edible Coating and Films to Improve Food Quality. A Technomic Publishing Company Inc. Lancester, Pensylvania. USA. p. 305-335.

Deberaufort, F., Martin Polo, M. and Voiley, A. 1993. Polarity homogeneity and structure affect water vapor permeability of model edible film. J. Food Sci. 58: 426-434.

Donhowe, G. and Fennema, O. 1994. Edible film and coating: Characteristic, formation, definitions and testing methods. In Krochta, J.M., Baldwin, E.A. and Nisperos-Carriedo, M.O. (eds.). Edible Coating and Film to Improve Food Quality. Technomic Publ. Co. Inc. Lancaster, Pennsylvania. 378 pp.

Gontard, N., Guilbert, S. and Cuq, J.L. 1993. Water and glycerol as plasticizer effect mechanical and water vapor barrier properties of an edible wheat gluten film. J. Food. Sci. 58(1): 206-210.

Irianto, H.E., Darmawan, M. dan Mindarwati, E. 2006. Pembuatan edible film dari komposit karaginan, tepung tapioka dan lilin lebah (beeswax). J. Penel. Perik. Indonesia. 1(2): 93-101.

Kinzel, B. 1992. Protein Rich Edible Coatings for Foods. Agricultural Research. May 1992. p. 20-21.

Krochta., J.M. 1992. Control of mass transfer in food with edible coatings and film. In Singh, R.P. and Wirakartakusumah, M.A. (eds.). Advances in Food Engineering. CRC Press: Boca Raton, F.L. p. 517538.

Krochta, J.M and Johnston, C.M. 1997. Edible and biodegradable polymer films. J. Food Technology 51(2): 61-74.

McHugh, T.H. dan Krochta, J.M. 1994. Permeability properties of edible films. In Krochta, J.M., Baldwin, E.A. and Nisperos-Carriedo, M.O. (eds.). Edible Coating and Film to Improve Food Quality. Lancaster-Basel. p. 139-187.

Melia, S. 1997. Pengaruh Penambahan Beeswax dan Methylcellulose dengan Plasticizer Gliserol terhadap Karakteristik Edible Film Bungkil Kacang Kedelai. Skripsi. Fakultas Teknologi Pertanian. Institut Pertanian Bogor. 102 pp.

Santoso, B. 2006. Karakterisasi komposit edible film buah kolang-kaling (Arenge Pinnata) dan lilin lebah. J. Teknologi \& Industri Pangan. 17(2):125-135.

Soekarto, S.T. 1985. Penilaian Organoleptik untuk Industri Pangan dan Hasil Pertanian. Bhratara Karya Aksara. Jakarta. 135 pp.

Steel, R.G.D. and Torrie, J.H. 1995. Prinsip dan Prosedur Statistika: Suatu Pendekatan Biometrik. Sumantri, B. (Penterjemah). PT. Gramedia Utama. Jakarta. 356 pp.

Suryaningrum, Th.D., Basmal, J. dan Nurrochmawati. 2005. Studi pembuatan edibel film dari karagenan. J. Penel. Perik. Indonesia. 2(4): 1-13.

Yunizal 2000. Penelitian Teknologi Ekstraksi Alginat dari Rumput Laut Coklat (Phaeophyceae). Balai Penelitian Perikanan Laut ,Jakarta. 100 pp. 
